\title{
PENILAIAN BERBASIS TEST DI SEKOLAH MINGGU
}

\author{
Yudha Nata Saputra \\ Sekolah Tinggi Teologi Cipanas \\ Jalan Gadog 1 No. 36 Cipanas 43253 Jawa Barat \\ Email: yudhanata99@gmail.com
}

\begin{abstract}
Assessment as a component of learning in Sunday schools plays an important role as a measure of success in achieving Sunday school goals. Without an assessment, parents, the church, Sunday school teachers, children cannot know the extent of their success in learning in the Sunday school. This paper tries to highlight aspects of assessment in Sunday school, specifically to the factors related to the use of test-based assessment techniques that can be used in the learning process in Sunday school. It is expected that by examining the factors related to the use of test-based assessment techniques, Sunday school teachers can use them in Sunday school services that are conducted. The results of the study show that test-based assessment techniques used in Sunday schools need to pay attention to the competencies that are intended to be mastered by Sunday school children and the types of learning material delivered to Sunday school children. In addition to paying attention to aspects of competency and types of learning material, the selection of test-based assessment techniques in Sunday schools also needs to pay attention to aspects of the feasibility and economics.
\end{abstract}

Keywords: Assessment, Sunday School, Test, Competence.

\begin{abstract}
ABSTRAK:Penilaian sebagai salah satu komponen pembelajaran di Sekolah Minggu, memegang peranan yang penting sebagai alat ukur keberhasilan pencapaian tujuan Sekolah Minggu. Tanpa adanya penilaian maka orang tua, gereja, guru Sekolah Minggu, anak-anak tidak bisa mengetahui sejauhmana keberhasilan mereka menjalani proses pembelajaran di Sekolah Minggu. Tulisan ini mencoba menyoroti aspek penilaian di Sekolah Minggu, secara khusus kepada faktor-faktor yang terkait dengan penggunaan teknik penilaian berbasis test yang bisa digunakan dalam proses pembelajaran di Sekolah Minggu. Diharapkan dengan dikajinya faktor-faktor terkait pengunaan teknik penilaian berbasis test maka guruguru Sekolah Minggu dapat menggunakannya dalam pelayanan Sekolah Minggu yang dilakukan. Hasil kajian menunjukkan bahwa teknik penilaian berbasis test yang digunakan di Sekolah Minggu perlu memerhatikan kompetensi yang hendak dikuasai oleh anak Sekolah Minggu dan jenis materi pembelajaran yang disampaikan kepada anak Sekolah Minggu. Di samping perhatian terhadap aspek kompetensi dan jenis materi pembelajaran, pemilihan teknik penilaian berbasis test di Sekolah Minggu juga perlu memerhatikan aspek praktibilitas dan ekonomis.
\end{abstract}

Kata kunci: Penilaian, Sekolah Minggu, Test, Kompetensi.

\section{PENDAHULUAN}

Sekolah Minggu yang dicetuskan oleh Robert Raikes pada tahun 1780 di Inggris, memberikan dampak yang besar bagi gereja. Tujuan didirikannya Sekolah Minggu pada mulanya adalah untuk mengajari anak-anak yang tidak mampu supaya belajar membaca dan menulis agar bisa membaca Alkitab ternyata mendapatkan sambutan yang sangat baik dari gereja sehingga sampai dengan saat ini Sekolah Minggu merupakan bagian yang tidak terpisahkan dari kegiatan gereja.
Sekolah Minggu sebagai sarana pendidikan bagi anak-anak, untuk mereka bisa belajar mengenai Firman Tuhan sehingga memiliki fondasi iman yang kokoh untuk bekal mereka menjalani kehidupan di masyarakat sehingga bisa menjadi terang dan garam dunia. Maka tentunya Sekolah Minggu perlu memerhatikan kegiatan pembelajarannya sehingga memberikan hasil sebagaimana yang diharapkan.

Sekolah Minggu sebagai bagian dari pelayanan Gereja yang berfokus kepada anak-anak sebagai anggotanya, juga didalamnya merupakan sebuah sistem pendidikan. Sekolah Minggu sebagai sebuah sis- 
tem pendidikan, di dalamnya tentu terdapat komponen-komponen yang berkaitan satu sama lainnya dalam rangka mencapai tujuan yang telah ditetapkan.

Terdapat beberapa komponen dalam Sekolah Minggu, yaitu anak-anak, guru Sekolah Minggu, kurikulum, sarana dan prasarana Sekolah Minggu, administrasi Sekolah Minggu, pendanaan Sekolah Minggu, kebijakan gereja, politik, sosial, budaya, keamanan, di mana setiap komponen-komponen tadi akan saling berinteraksi yang memengaruhi proses pembelajaran di Sekolah Minggu yang berdampak pada pencapaian tujuan Sekolah Minggu. Di antara sekian banyak komponen sistem Sekolah Minggu, komponen kurikulum memegang peranan yang penting dalam pencapaian tujuan Sekolah Minggu. Bahkan peranan kurikulum tidak sebatas dalam hal pencapaian tujuan Sekolah Minggu saja, tapi lebih dari itu kurikulum memiliki peran dalam menentukan pengalaman belajar yang harus dimiliki oleh anak dan bagaimana mereka mengorganisasi pengalaman belajar itu (Sanjaya, 2011).

Keberhasilan Sekolah Minggu dalam membentuk anak-anak yang telah dipercayakan Tuhan kepada orang tua dan gereja akan ditentukan oleh sejauh mana mereka memiliki pengalaman belajar yang berarti selama mereka mengikuti kegiatan di Sekolah Minggu. Sehingga melalui pengalaman belajar yang berarti ini akan menjadi bekal mereka kelak dalam menjalani kehidupan sebagai umat Tuhan, baik itu di dalam keluarga, gereja maupun masyarakat. Mengingat pentingnya kurikulum dalam pembelajaran di Sekolah Minggu, maka tentu pihak gereja perlu memberikan perhatian terhadap kurikulum Sekolah Minggu yang hendak diterapkan dalam Sekolah Minggu. Ketika berbicara kurikulum Sekolah Minggu, tentu tidak sesederhana yang diucapkan. Tapi secara operasional terdapat setidaknya empat komponen pembentuk kurikulum Sekolah Minggu, yaitu tujuan pendidikan Sekolah Minggu, bahan ajar Sekolah Minggu, metode pembelajaran Sekolah Minggu dan penilaian Sekolah Minggu. Dalam hal tujuan Sekolah Minggu, tentunya setiap gereja memiliki tujuannya masing-masing sesuai dengan visi- misi yang sudah Tuhan taruh kepada gereja-Nya. Bahan ajar Sekolah Minggu, sudah banyak buku-bu$\mathrm{ku}$ yang diterbitkan oleh lembaga-lembaga penerbitan Kristen yang bisa digunakan sesuai dengan kebutuhan Sekolah Minggu. Begitu pula, metode-metode mengajar Sekolah Minggu, sudah banyak dikembangkan oleh ahli-ahli pendidikan Kristen. Namun berbicara tentang penilaian di Sekolah Minggu, aspek ini belum banyak disentuh.

Bicara penilaian, bahkan dalam praktik Sekolah Minggu, jarang guru Sekolah Minggu melakukan penilaian kepada anak-anak Sekolah Minggu sehingga kegiatan Sekolah Minggu dari waktu ke waktu tidak banyak mengalami perubahan. Tentu yang dimaksud penilaian di sini tidak melulu bersifat formal layaknya seorang anak belajar di SD atau SMP melalui ujian mengerjakan soal-soal untuk menentukan kelulusan, tapi ada bentuk-bentuk penilaian lain yang sebenarnya bisa dimanfaatkan oleh guru Sekolah Minggu dalam melaksanakan tugasnya.

Penilaian merupakan bagian integral dari proses pembelajaran. Penilaian sering dianggap sebagai salah satu dari tiga pilar utama yang sangat menentukan kegiatan pembelajaran. Ketiga pilar tersebut adalah perencanaan, pelaksanaan dan penilaian. Apabila ketiga pilar tersebut sinergis dan berkesinambungan, maka akan sangat menentukan kualitas pembelajaran (Muchtar, 2010).

Penilaian sebagai salah satu komponen kurikulum Sekolah Minggu, memegang peranan yang penting sebagai alat ukur keberhasilan pencapaian tujuan Sekolah Minggu (Mardapi, 2012). Tanpa adanya penilaian maka orang tua, gereja, guru Sekolah Minggu, anak-anak tidak bisa mengetahui sejauhmana keberhasilan mereka menjalani proses pembelajaran di Sekolah Minggu.

Sebaliknya melalui aktivitas penilaian, orang tua bisa melihat sejauhmana keberhasilan anak-anak mereka mengikuti proses pembelajaran di Sekolah Minggu sehingga akan menambah semangat mereka untuk belajar (Azwar, 2012). Gereja bisa mengetahui sejauhmana tujuan Sekolah Minggu yang telah ditetapkannya mencapai keberhasilan. Guru Sekolah Minggu, bisa mengetahui sejauhmana prestasi anak- 
anak Sekolah Minggu yang sudah Tuhan percayakan kepadanya untuk dididik. Anak-anak bisa mengetahui sejauhmana ia telah berhasil mengikuti proses belajar di Sekolah Minggu. Sehingga melalui penilaian ini, bisa menjadi umpan balik bagi masing-masing pihak untuk terus memperbaiki dirinya dalam melayani pekerjaan Tuhan (Gery, Mering, \& Silaban, 2018).

Pentingnya penilaian dalam pembelajaran anak diungkapkan oleh beberapa hasil penelitian, diantaranya penelitian yang dilakukan Zahro menawarkan penilaian kepada anak melalui teknik observasi, wawancara, penugasan dan ujuk kerja dan pemeriksaan medis (Zahro, 2015). Yusuf (2009) mengemukakan beberapa assesmen yang bisa diberikan kepada anak, yaitu: observasi, pencatatan, checklist, documenting, portofolio, dan authentic assessment (Iswantiningtyas \& Wulansari, 2018). Sementara itu penelitian Widayati menemukan bahwa terdapat dua bentuk penilaian yang digunakan guru dalam menilai perkembangan anak yaitu penilaian checklist dan penilaian narasi, tapi penelitian Widayati juga mengungkapkan temuan bahwa guru mengalami kesulitan dalam melakukan penilaian baik checklist maupun narasi (Widayati, 2013). Hambatan dalam penilaian checklist yaitu memerlukan waktu dan ketelitian guru, sedangkan hambatan dalam penilaian narasi, yaitu menuntut kemampuan yang baik dari guru dalam memberikan uraian (Widayati, 2013). Sesuai dengan karakteristik kegiatan belajar di Sekolah Minggu yang padat aktivitas dengan kemampuan guru Sekolah Minggu yang beragam dan waktu yang terbatas maka penilaian bagi anak Sekolah Minggu perlu menggunakan teknik penilaian yang mudah, praktis dan cepat dilaksanakan. Dalam hal ini, maka teknik penilaian berbasis test yang selama ini jarang digunakan untuk menilai hasil belajar kepada anak perlu dikaji terhadap kemungkinan penerapannya di Sekolah Minggu.

Mencermati kenyataan di atas maka masalah dalam tulisan ini dirumuskan sebagai berikut: Bagaimana menyusun penilaian berbasis Test untuk diterapkan di Sekolah Minggu? Adapun tujuan yang hendak dicapai melalui penulisan artikel ini, yaitu mendeskripsikan penyusunan penilaian berbasis Test yang bisa diterapkan di Sekolah Minggu.

\section{METODE}

Metode yang digunakan dalam tulisan ini, yaitu studi kepustakaan, hal ini sesuai dengan tujuan dalam tulisan ini, yaitu untuk mengkaji penggunaan teknik penilaian berbasis test yang bisa digunakan di Sekolah Minggu. Adapun langkah-langkah yang dilakukan dalam studi kepustakaan ini, yaitu menentukan sumber-sumber bacaan yang relevan dengan tujuan penulisan yang berasal dari perpustakaan. Setelah menentukan sumber-sumber bacaan yang relevan, selanjutnya yaitu membaca buku-buku dan hasil-hasil penelitian terdahulu yang terkait dengan topik tulisan, dicermati dengan teliti agar bisa memperoleh bahan-bahan yang diperlukan. Selanjutnya, menuangkannya dalam bentuk tulisan. Untuk memperoleh data yang tepat, maka proses pencarian sumber-sumber yang relevan, proses membaca bahanbahan dilakukan secara berulang-ulang sehingga bisa diperoleh data yang baik, termasuk penulisan bahan juga dilakukan secara cermat dan berulangulang sehingga bisa dipahami maksudnya.

\section{PEMBAHASAN}

\section{Penilaian Di Sekolah Minggu}

Dalam kegiatan evaluasi, terdapat dua kegiatan yaitu pengukuran dan penilaian. Pengukuran adalah kegiatan memberikan skor/angka-angka sehingga bersifat kuantitatif sedangkan penilaian adalah kegiatan memberikan keputusan berdasarkan pengukuran (Arikunto, 2014). Misalnya, jika seorang anak mendapatkan nilai ulangan sebesar 50 maka anak tersebut dikatakan tidak lulus. Skor yang diperoleh anak sebesar 50 itu merupakan kegiatan pengukuran, berdasarkan skor 50 maka anak itu dikatakan tidak lulus merupakan kegiatan penilaian.

Dengan melihat contoh di atas, maka bisa dikatakan bahwa kegiatan pengukuran akan mendahului kegiatan penilaian. Di dalam Sekolah Minggu, 
tentu kegiatan penilaian ini memiliki tujuan yang berbeda dengan kegiatan penilaian yang dilakukan di sekolah pada umumnya, jika di sekolah penilaian dikaitkan dengan lulus tidaknya seorang anak dalam menempuh suatu program pendidikan yang ditetapkan, seperti kenaikan kelas maka di Sekolah Minggu kegiatan penilaian tidak ditujukan untuk kelulusan tapi kegiatan penilaian di Sekolah Minggu ditujukan sebatas untuk mengetahui keberhasilan anak dalam mengikuti program kegiatan Sekolah Minggu yang berjalan dalam sebuah gereja (Luhulima, Degeng, \& Ulfa, 2017).

Pada proses pembelajaran di Sekolah Minggu Klasis Kota Ambon, tidak terdapat sebuah ketentuan nilai KKM untuk menilai hasil belajar anak apakah tuntasataukah tidak seperti yang terdapat pada proses pembelajaran di sekolah formal. Karena pada dasarnya proses pembelajaran yang terjadi di Sekolah Minggu bertujuan untuk mendidik dan mendewasakan anak dan remaja GPM untuk memiliki karakter seperti yang diinginkan oleh Yesus Kristus Tuhan dan menanamkan kemampuan intelektual sesuai kebenaran firman Tuhan. Sehingga untuk mengukur hasil belajar anak dilihat melalui ketercapaian - ketercapaian tujuan khusus pada setiap pembelajaran melalui aktifitas - aktifitas yang diberikan oleh pengajar Sekolah Minggu, seperti diskusi bersama, hasil tes lisan atau hasil tes tertulis yang dibuat oleh pengajar Sekolah Minggu (Luhulima et al., 2017).

Dengan demikian maka penilaian di Sekolah Minggu cukup saja diberikan predikat Baik-Cukup-Kurang, hal ini mengingat dalam Sekolah Minggu tidak ada istilah lulus/tidak lulus. Meskipun demikian tidak berarti hasil kegiatan penilaian di Sekolah Minggu tidak bermanfaat, dengan penilaian yang diberikan kepada anak Sekolah Minggu maka ini tetap berguna untuk mengetahui keberhasilan siswa (Mahirah, 2017) dalam mengikuti kegiatan Sekolah Minggu sehingga bisa menjadi umpan balik bagi anak, orang tua, guru Sekolah Minggu dan gereja.

Melalui penilaian yang diberikan, maka anak akan mengetahui sejauh mana ia berhasil mengikuti program pendidikan (Setemen, 2010) di Sekolah Minggu tanpa perlu merasa dibebani dengan konsekuensi lulus/tidak lulus. Justru inilah yang men- jadi hakikat penilaian dalam Pendidikan Kristen, penilaian tidak digunakan untuk menjadi ajang persaingan antar anak tapi penilaian bertujuan untuk mengukur keberhasilan anak dalam menjalani sebuah program pendidikan di mana melalui hasil penilaian ini maka anak bisa mengetahui sejauh mana potensi dirinya telah di kembangkan (Edlin, 2015).

Orang tua pun tentu akan merasa senang dengan adanya penilaian yang diberikan kepada anak selama mereka mengikuti pendidikan di Sekolah Minggu, orang tua bisa mengetahui sejauh mana kemampuan anaknya dalam mengikuti program pendidikan (Zahro, 2015) di Sekolah Minggu. Jika ternyata hasilnya kurang maka orang tua bisa memberikan motivasi kepada anaknya supaya meningkatkan kemampuannya (Handhika, 2012) sementara jika hasilnya baik maka orang tua bisa memberikan motivasi kepada anaknya untuk mempertahankannya.

Guru Sekolah Minggu pun akan merasakan manfaat dengan adanya kegiatan penilaian yang mungkin selama ini tidak pernah dilakukan. Melalui penilaian, seorang guru Sekolah Minggu bisa mengetahui prestasi anak-anak Sekolah Minggunya sehingga bisa menjadi umpan balik bagi dirinya (Mahirah, 2017), sejauh mana ia telah berhasil mendidik anakanak Sekolah Minggu yang telah Tuhan percayakan kepadanya.

Melalui kegiatan penilaian, maka gereja pun akan dapat mengetahui sejauh mana kebijakan-kebijakan yang diterapkannya berkaitan dengan Sekolah Minggu sudah mencapai keberhasilan (Gery et al., 2018). Jika banyak anak Sekolah Minggu yang mendapatkan penilaian yang baik, artinya kebijakan gereja sudah memberikan hasil yang memuaskan namun sebaliknya jika banyak anak Sekolah Minggu yang penilaiannya kurang maka tentunya gereja perlu meninjau kebijakannya berkaitan dengan program Sekolah Minggu, ada sesuatu yang perlu diperbaiki.

Dengan melihat manfaat adanya kegiatan penilaian di Sekolah Minggu, maka hal ini akan memacu anak, orang tua, guru Sekolah Minggu dan gereja untuk senantiasa memperbaiki diri karena pekerjaan yang mereka lakukan bukan hanya sekedar 
aktivitas pendidikan seperti biasa tapi sebuah pekerjaan yang telah dipercayakan oleh Tuhan sehingga perlu dikerjakan sebaik-baiknya untuk kemuliaan nama Tuhan (Kol. 3:23).

Terdapat sedikitnya tiga fungsi penilaian secara umum, yaitu fungsi placement (penempatan), fungsi diagnostik dan fungsi saringan. Fungsi placement, ditujukan untuk menempatkan seseorang sesuai dengan minat dan bakatnya dalam hal ini, penilaian yang berfungsi placement biasanya digunakan untuk pemilihan jurusan baik itu di SMA maupun di perguruan tinggi (Arikunto, 2014). Tujuannya dari penilaian yang berfungsi placement, yaitu untuk menempatkan anak dalam suatu program pendidikan yang sesuai dengan minat dan bakatnya.

Fungsi diagnostik, yaitu fungsi penilaian untuk mengukur sejauh mana keberhasilan anak dalam mengikuti suatu program pendidikan sehingga bisa diketahui hambatan-hambatan yang dihadapinya. Sesuai dengan namanya maka penilaian yang berfungsi diagnostik ingin mengetahui kecocokan suatu program pendidikan yang sedang dijalani.

Fungsi saringan, yaitu fungsi penilaian untuk meramalkan kemampuan seseorang dalam menjalani sebuah program pendidikan yang ingin dijalaninya. Karena sifatnya yang demikian maka penilaian yang menjalankan fungsi saringan biasanya memiliki tingkat kesulitan yang tinggi karena sifatnya yang prediktif.

Dengan mencermati fungsi-fungsi penilaian dalam suatu program pendidikan maka bisa diketahui bahwa fungsi penilaian yang sesuai digunakan di Sekolah Minggu. Penilaian di sekokah minggu tidak berfungsi placement karena setiap anak di Sekolah Minggu ditempatkan biasanya berdasarkan usianya, karena dari sudut pandang psikologi perkembangan, setiap orang memiliki kebutuhan yang berbeda sesuai dengan usianya. Di setiap gereja biasanya terdapat beberapa kelas Sekolah Minggu, yaitu kelas Kanak-kanak usia 4-6 tahun, kelas Pratama usia 7-9 tahun, dan kelas Madya usia 10-12 tahun (AGLCTeaching Ministries Acra, n.d.), pembagian kelas Sekolah Minggu ini lebih baik jika dilakukan sejak awal agar Sekolah Minggu bisa berjalan secara efektif (Lie, 2003).

Demikian pula, di Sekolah Minggu tidak dikenal istilah lulus atau tidak lulus dalam mengikuti kegiatan di Sekolah Minggu (Muchtar, 2010) sehingga tidak diperlukan semacam ujian saringan untuk mengetahui apakah seorang anak akan berhasil atau tidak dalam mengikuti program pendidikan di Sekolah Minggu. Karena penilaian di Sekolah Minggu tidak berfungsi placement maupun saringan maka penilaian yang cocok digunakan di Sekolah Minggu, yaitu penilaian yang berfungsi diagnostik, penilaian yang dilakukan untuk mengetahui kesulitan-kesulitan belajar yang dihadapi anak selama mengikuti kegiatan Sekolah Minggu sehingga bisa diberikan penanganan yang tepat (Yusuf, 2015).

Meskipun penilaian di Sekolah Minggu hanya berfungsi diagnostik namun dalam pelaksanaannya tetap perlu memerhatikan prinsip-prinsip penilaian yang berlaku, yaitu sahih, objektif, adil, terpa$\mathrm{du}$, terbuka, menyeluruh dan berkesinambungan, sistematis, beracuan kriteria, akuntabel (Indonesia, 2016). Sahih artinya penilaian yang dilakukan di Sekolah Minggu perlu berdasarkan data yang mencerminkan kemampuan yang hendak diukur (Arikunto, 2014). Jika penilaian hendak mengukur minat anak Sekolah Minggu dalam meneladani sosok Yesus sebagai Tuhan, maka data yang perlu dikumpulkan adalah data sikap anak Sekolah Minggu terhadap sosok Yesus, bukan data pengetahuan anak Sekolah Minggu terhadap sosok Yesus sebagai Tuhan.

Objektif, artinya penilaian yang dilakukan kepada anak Sekolah Minggu harus berdasarkan kriteria dan prosedur yang jelas sehingga terbebas dari unsur subyektifitas (Indonesia, 2016). Jika guru Sekolah Minggu hendak memberikan penilaian baik kepada salah seorang anak Sekolah Minggu, maka tentunya hal itu tidak dilakukan karena guru menyukai penampilan anak Sekolah Minggunya tapi memang berdasarkan kriteria yang sudah ditetapkan sebelumnya. Misalnya, seorang anak Sekolah Minggu akan mendapatkan penilaian baik, jika aktif dalam mendengarkan cerita Sekolah Minggu, selalu 
hadir tepat waktu setiap minggunya, bersikap sopan terhadap anak yang lain dan menaruh hormat kepada guru Sekolah Minggu.

Adil, artinya penilaian yang diberikan kepada anak Sekolah Minggu tidak menguntungkan dan tidak merugikan karena berkebutuhan khusus, atau perbedaan latar belakang suku,budaya, sosial ekonomi, gender (Indonesia, 2016). Sebagai contoh, jika penilaian yang diberikan kepada kemampuan anak Sekolah Minggu dalam menyanyikan lagu rohani dalam bahasa daerah tertentu, maka tentunya anak Sekolah Minggu yang bukan berasal dari daerah di mana bahasa daerah itu berasal akan dirugikan.

Terpadu, artinya penilaian merupakan bagian yang tidak terpisahkan dari kegiatan pembelajaran (Indonesia, 2016). Anak-anak yang tidak mengikuti Sekolah Minggu, tidak bisa diberikan penilaian untuk mengetahui keberhasilan mereka, demikian juga kegiatan Sekolah Minggu memiliki kedudukan yang sama pentingnya dengan kegiatan penilaian.

Terbuka, artinya prosedur penilaian, kriteria penilaian dan pengambilan keputusan dalam penilaian dapat diketahui oleh orang tua, anak, guru Sekolah Minggu, gereja tanpa ada hal yang disembunyikan (Indonesia, 2016). Ketika orang tua ingin mengetahui kriteria yang digunakan oleh guru Sekolah Minggu dalam memberikan nilai baik kepada anaknya, maka guru Sekolah Minggu perlu memberikan informasi dengan jelas.

Menyeluruh dan berkesinambungan, artinya penilaian dilakukan untuk mengukur semua hal yang sudah dipelajari dengan menggunakan teknik penilaian yang sesuai (Indonesia, 2016). Jika anak-anak sudah diajarkan tentang pentingnya berdoa sebagai orang percaya, perlunya mengucap syukur setiap kali akan menyantap makanan maka kedua aspek tadi perlu ada dalam penilaian dengan menggunakan teknik penilaian yang sesuai.

Sistematis, artinya penilaian dilakukan secara bertahap dan terencana dengan langkah-langkah yang sudah ditetapkan sebelumnya (Indonesia, 2016). Tidak ada yang namanya guru Sekolah Minggu memberikan penilaian mendadak tanpa persiapan, hanya karena anak-anak Sekolah Minggu tidak mau mendengarkan cerita guru Sekolah Minggu. Begitu pula, penilaian yang dilakukan oleh guru Sekolah Minggu tidak bisa dilakukan sekali saja, namun dalam setiap kesempatan yang sudah direncanakan sebelumnya.

Beracuan kriteria, artinya penilaian dilakukan merujuk kepada tujuan yang telah ditetapkan sebelumnya (Indonesia, 2016). Penilaian kepada anak-anak Sekolah Minggu harus berdasarkan tujuan yang telah ditetapkan sebelumnya, jika anak-anak Sekolah Minggu diharapkan mampu menyadari kebesaran Tuhan dalam ciptaan-Nya, maka penilaian tidak dilakukan kepada kemampuan anak-anak Sekolah Minggu untuk menyebutkan mahluk-mahluk ciptaan Tuhan.

Akuntabel, artinya penilaian yang diberikan kepada anak Sekolah Minggu harus dapat dipertanggungjawabkan kepada Tuhan dan kepada semua pihak yang terkait (Indonesia, 2016). Inilah yang menjadi pembeda penilaian umum dengan penilaian dalam Sekolah Minggu, penilaian dalam Sekolah Minggu yang dilakukan oleh guru-guru Sekolah Minggu bukan hanya dipertanggungjawabkan kepada manusia tapi juga kepada Tuhan (Mat. 18:6).

\section{Aspek-aspek Penilaian}

Proses penilaian merupakan bagian yang tak terpisahkan dari proses pembelajaran dan bersifat menyeluruh (holistik) yang mencakup semua aspek perkembangan anak didik baik aspek sikap, ilmu pengetahuan maupun keterampilan (Zahro, 2015). Demikian pula penilaian di Sekolah Minggu, pada dasarnya merupakan upaya untuk mengukur aspekaspek kompetensi anak Sekolah Minggu yang terdiri dari aspek berpikir (kognitif), aspek sikap (afektif) dan keterampilan (psikomotor) yang dikenal dengan sebutan taksonomi. Aspek berpikir adalah kemampuan anak yang berkaitan dengan tingkatan kemampuan intelektual, menurut Bloom terdiri dari mengingat, memahami, penerapan, analisis, evaluasi dan mencipta (Prasetya, 2012). Aspek sikap adalah kemampuan anak yang berkaitan dengan tingkatan ke- 
mampuan untuk merasakan (emosi), menurut Krathwhol terdiri dari menerima, merespon, menghargai, mengorganisasi, karakterisasi (Prasetya, 2012). Aspek keterampilan adalah kemampuan anak dalam melakukan aktivitas motorik, yang terdiri dari meniru, manipulasi, presisi, artikulasi, naturalisasi.

Aspek-aspek kompetensi anak Sekolah Minggu, yang terdiri dari aspek berpikir, aspek sikap dan aspek keterampilan ini memiliki sifat bertingkat dalam kompetensi anak, dari mulai yang paling rendah (mengingat) sampai yang paling tinggi (mencipta), dari yang sifatnya sederhana (low level thinking order) sampai kepada yang kompleks (higher level thinking order), meskipun aspek-aspek dalam kompetensi anak Sekolah Minggu ini dapat dibedakan tapi dalam kenyataannya ketiga aspek, kognitif, afektif, psikomotor ini merupakan sebuah kesatuan yang menjadi pembentuk kompetensi anak Sekolah Minggu.

Mengingat, sifat ketiganya yang hanya bisa dibedakan namun tidak bisa dipisahkan maka pada dasarnya sebuah proses pembelajaran dapat dipahami sebagai upaya untuk mengembangkan keterampilan berpikir seorang anak. Instrumen penilaian yang dirancang dengan baik dan sesuai dengan tingkatan kemampuan berpikir dapat meningkatkan daya berpikir siswa (Amalia \& Susilaningsih, 2014). Hasil yang diharapkan melalui peningkatan keterampilan berpikirnya maka seorang anak dapat menjalankan tugas-tugas perkembangannya sebagai individu maupun tugas-tugas perkembangannya sebagai bagian masyarakat.

Penilaian sebagai bagian yang tidak terpisahkan dalam proses pembelajaran anak Sekolah Minggu, tentunya perlu memerhatikan aspek-aspek yang tercakup dalam kompetensi anak Sekolah Minggu yang menjadi tujuan dari proses pembelajaran di Sekolah Minggu. Penyusunan instrumen penilaian maupun penggunaan teknik penilaian yang akan dipakai sudah seharusnya memerhatikan aspekaspek kompetensi untuk menjaga validitas dan reliabilitasnya sehingga hasilnya akan memberikan manfaat bagi pihak-pihak yang berkepentingan mau- pun dalam rangka pengambilan keputusan (Gery et al., 2018) dalam menjalankan program-program Sekolah Minggu di masa mendatang.

\section{Materi Pembelajaran}

Dick dan Carey menegaskan bahwa kompetensi dasar merupakan komponen kunci suatu program pembelajaran, yang merupakan petunjuk dalam memilih materi, kegiatan pembelajaran dan pengembangan instrumen evaluasi (L \& Sitompul, 2016). Materi pembelajaran adalah konten dalam pencapaian kompetensi anak Sekolah Minggu. Dalam kaitannya dengan penilaian berbasis test di Sekolah Minggu, maka materi pembelajaran menurut Merril (1977) dibedakan dalam empat jenis yaitu: fakta, konsep, prosedur, dan prinsip (Sanjaya, 2015). Fakta, yaitu segala sesuatu yang berhubungan dengan kebenaran dan kenyataan (Sanjaya, 2011), seperti nama tempat, nama orang, nama benda peristiwa. Karena sifatnya yang berkaitan dengan aspek mengingat saja maka fakta merupakan materi pembelajaran Sekolah Minggu yang paling sederhana.

Konsep, yaitu materi pembelajaran Sekolah Minggu yang berbentuk pengertian-pengertian baru sebagai hasil berpikir (Sanjaya, 2011). Materi pembelajaran konsep dapat berbentuk definisi, pengertian, hakekat, ciri-ciri khusus. Untuk bisa mempelajari bahan pembelajaran berbentuk konsep, maka anak Sekolah Minggu perlu belajar dulu tentang materi pembelajaran fakta. Contohnya, dosa adalah sebuah konsep, untuk bisa mengerti dosa maka seorang anak Sekolah Minggu, perlu mengetahui dulu fakta tentang Allah, peraturan dan manusia. Karena dosa dipahami sebagai pelanggaran yang dilakukan oleh manusia terhadap ketetapan-ketetapan (peraturan) Allah.

Prinsip, yaitu materi pembelajaran Sekolah Minggu yang berisi hal-hal pokok (Sanjaya, 2011). Termasuk dalam materi pembelajaran prinsip, yaitu dalil, hukum, postulat, rumus, paradigma, termasuk hubungan antar konsep. Karena sifatnya, yang lebih komplek maka untuk bisa mempelajari materi pembelajaran prinsip, seorang anak Sekolah Minggu per- 
lu menguasai terlebih dahulu materi pembelajaran konsep. Contohnya, untuk anak Sekolah Minggu bisa memahami bahwa upah dosa adalah maut sehingga manusia memerlukan keselamatan, maka anak Sekolah Minggu perlu mengerti terlebih dahulu konsep upah, konsep dosa, konsep maut, konsep keselamatan.

Prosedur, yaitu materi pembelajaran yang berisi langkah-langkah sistematis atau kronologis dalam mengerjakan sesuatu (Sanjaya, 2011). Untuk bisa belajar materi pembelajaran prosedur maka seorang anak Sekolah Minggu perlu belajar terlebih dahulu materi pembelajaran prinsip, karena pada dasarnya materi pembelajaran prosedur merupakan penerapan dari prinsip-prinsip yang sudah dipelajari oleh seorang anak Sekolah Minggu. Contohnya, untuk seorang anak Sekolah Minggu bisa menerima keselamatan maka seorang anak Sekolah Minggu perlu terlebih dahulu menyadari keberadaannya sebagai manusia yang berdosa, menyesali dosanya dan bertobat lalu menerima Yesus sebagai Tuhan dan Juruselamat.

Dengan memahami, jenis-jenis materi pembelajaran yang bisa digunakan dalam memilih teknik penilaian di Sekolah Minggu maka bisa dikatakan pemilihan teknik penilaian berbasis test di Sekolah Minggu dalam rangka pencapaian kompetensi akan berhasil jika mempertimbangkan jenis materi yang perlu dikuasai oleh anak Sekolah Minggu, tanpa itu teknik penilaian berbasis test yang dipakai akan sulit untuk dapat mencapai tujuan.

\section{Teknik Penilaian Berbasis Test}

Secara umum, teknik penilaian berbasis test meliputi test obyektif dan test non obyektif (Yusuf, 2015). Test obyektif meliputi test Benar-Salah (B$\mathrm{S})$, test pilihan ganda dan test menjodohkan sedangkan test non obyektif meliputi jawaban singkat dan essay. Teknik penilaian berbentuk tes biasanya digunakan untuk mengukur aspek pengetahuan (kognitif) anak (Arikunto, 2014). Aspek pengetahuan yang diukur, meliputi tingkatan berpikir yang paling rendah sampai ke yang paling tinggi, yaitu mengingat, me- mahami, menerapkan, menganalisa, mensintesis, mengevaluasi, mencipta (Arikunto, 2014).

Test Benar-Salah, digunakan jika guru Sekolah Minggu ingin mengetahui kemampuan anak dalam mengingat pelajaran yang telah disampaikan (Matondang, Djulia, Sriadhi, \& Simarmata, 2019). Karena sifatnya yang mengukur kemampuan anak untuk mengingat pelajaran yang telah disampaikan guru Sekolah Minggu maka jenis test benar-salah ini cocok digunakan untuk materi pelajaran Sekolah Minggu yang berbentuk fakta. Contohnya, tempat di mana Yesus dilahirkan, nama anak-anak Adam dan Hawa, waktu Allah menciptakan manusia, nama manusia pertama yang diciptakan Allah.

Tes menjodohkan, memiliki kemiripan dengan tes benar-salah yaitu dalam tujuan penggunaannya, untuk mengukur kemampuan anak dalam mengingat. Perbedaannya adalah dalam teknis pengerjaan saja, di mana anak diminta menghubungkan pernyataan di dua lajur yang berbeda sehingga terkesan lebih sulit dibandingkan tes benar salah. Dalam penggunaan tes menjodohkan maka yang perlu diperhatikan oleh guru Sekolah Minggu yaitu homogenitas soal, misalnya soal yang diberikan berkaitan dengan peristiwa-peristiwa dalam Alkitab beserta dengan nama tempatnya. Anak akan diminta untuk menjodohkan peristiwa dengan tempat terjadinya peristiwa.

Test pilihan ganda hampir sama dengan test benar-salah, digunakan oleh guru Sekolah Minggu jika ingin mengetahui kemampuan anak dalam mengingat, memahami dan menerapkan pelajaran yang telah diterimanya (Matondang et al., 2019). Dalam hal ini, test pilihan ganda memiliki kelebihan dalam hal mengukur aspek pengetahuan (kognitif) anakanak Sekolah Minggu dibandingkan dengan test Benar-Salah sehingga bisa digunakan bukan hanya materi pelajaran yang berbentuk fakta tapi juga materi pelajaran yang berbentuk konsep, prinsip, dan prosedur. Contohnya, jika guru ingin melihat kemampuan siswa dalam membuat urutan benda-benda yang diciptakan Allah dalam Kejadian 1, maka bisa menggunakan soal berbentuk pilihan ganda ini. 
Soal jawaban singkat adalah bentuk penilaian yang meminta anak Sekolah Minggu untuk memberikan jawaban singkat, karena sifatnya yang memberikan jawaban singkat maka bentuk soal jawaban singkat cocok digunakan mengetahui kemampuan anak Sekolah Minggu berkaitan dengan aspek ingatan untuk materi pembelajaran yang bersifat fakta dan konsep. Contoh materi pembelajaran yang bersifat fakta, yaitu Yusuf, ayah Yesus bekerja sebagai tukang kayu. Contoh materi pembelajaran yang bersifat konsep, yaitu pelanggaran yang dilakukan manusia terhadap perintah Allah disebut dosa.

Soal berbentuk essay adalah bentuk penilaian yang meminta anak Sekolah Minggu untuk memberikan jawaban berbentuk uraian, karena sifatnya yang demikian maka bentuk soal essay cocok digunakan untuk mengukur aspek pemahaman, penerapan, analisis dan evaluasi. Dengan sifat pengukuran yang lebih luas terhadap aspek berpikir yang diukur oleh bentuk soal essay ini, maka cocok digunakan untuk materi Sekolah Minggu yang berbentuk konsep, prinsip maupun prosedur. Contohnya, jelaskan yang dimaksud dengan doa (konsep-pemahaman), kapan sebaiknya orang percaya berdoa (konsep-penerapan), apa saja isi doa orang percaya (konsepanalisis), bagaimana sebaiknya kita berdoa (konsepevaluasi).

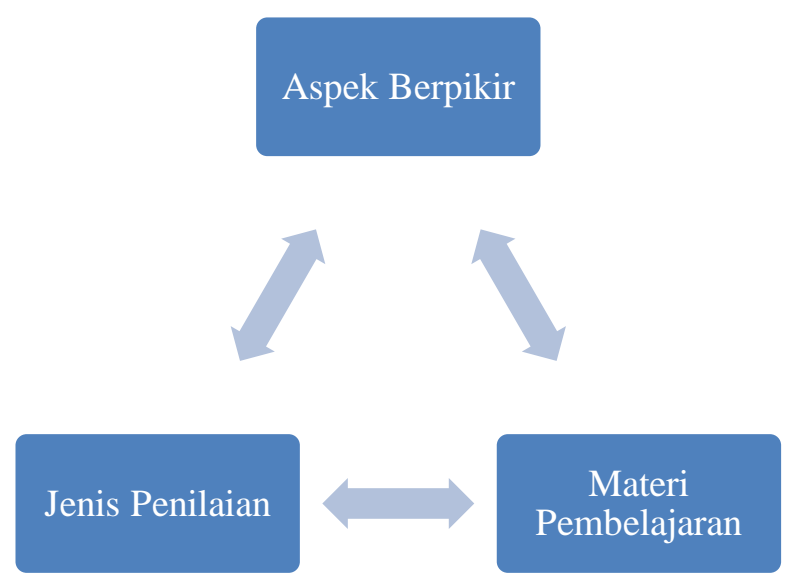

Gambar 1. Hubungan antara Aspek Berpikir, Materi dan Jenis Penilaian

Dengan mengamati gambar di atas, maka bisa dikatakan bahwa dalam menentukan teknik penilaian di Sekolah Minggu, akan ditentukan oleh as- pek berpikir yang hendak diukur, jenis materi pembelajaran yang disampaikan kepada anak Sekolah Minggu dan jenis penilaian. Di mana ketiganya merupakan komponen-komponen yang berkaitan satu dengan lainnya.

Selain ketiga aspek di atas, lain yang perlu diperhatikan dalam menentukan teknik penilaian yang digunakan di Sekolah Minggu adalah aspek praktibilitas dan ekonomis (Arikunto, 2014). Praktibilitas berkaitan dengan kemudahan dalam menyusun, melaksanakan dan memeriksa jenis penilaian yang dipilih sedangkan ekonomis berkaitan dengan aspek efisiensi (dana, tenaga, waktu) dalam hal penyusunan, pelaksanaan dan pemeriksanaan hasil penilaian. Pentingnya perhatian terhadap aspek praktibilitas dan ekonomi yaitu mencegah munculnya masalah yang berkaitan dengan jumlah unsur penilaian, kompleksitas penilaian, pembuatan instrumen penilaian, pelaksanaan penilaian, dan pelaporan hasil penilaian (Subagia\& Wiratma, 2016).

Aktivitas kegiatan Sekolah Minggu yang padat dengan waktu yang terbatas,tentunya perlu menjadi pertimbangan dalam memilih instrumen penilaian yang mudah dibuat, mudah digunakan dan mudah diolah sehingga bukan saja memenuhi unsur praktis tapi juga efisien(Arikunto, 2014). Kenyataan ini tidak dapat dipungkiri, mengingat kondisi guru Sekolah Minggu yang rata-rata sifatnya sukarela, sehingga memilih teknik penilaian yang terlampau rumit hanya akan membebani bukan saja guru Sekolah Minggu tapi juga anak Sekolah Minggu.

Hal ini perlu diperhatikan mengingat terdapat perbedaan penilaian dalam sekolah formal dengan penilaian dalam Sekolah Minggu, penilaian dalam Sekolah Minggu tidak ditujukan untuk membandingkan anak Sekolah Minggu dengan anak yang lain tapi untuk mengukur sejauhmana perkembangan yang ditunjukkan oleh anak-anak Sekolah Minggu (Edlin, 2015) sehingga tidak ada yang namanya ranking, karena sifatnya yang demikian maka teknik penilaian diSekolah Minggu lebih sederhana namun tetap bermanfaat. 


\section{KESIMPULAN}

Teknik penilaian berbasis test yang digunakan di Sekolah Minggu perlu memerhatikan kompetensi yang hendak dikuasai oleh anak Sekolah Minggu dan jenis materi pembelajaran yang disampaikan kepada anak Sekolah Minggu. Keberhasilan penggunaan teknik penilaian yang digunakan akan berdampak kepada pencapaian kompetensi anak Sekolah Minggu yang ditandai dengan pencapaian

\section{DAFTAR RUJUKAN}

AGLC-Teaching Ministries Acra. (n.d.). Pola Dasar Perkembangan Sekolah Minggu. Malang: Yayasan Penerbit Gandum Mas.

Amalia, N. F., \& Susilaningsih, E. (2014). Pengembangan Instrumen Penilaian Keterampilan Berpikir Kristis Siswa SMA pada Materi Asam Basa. Jurnal Inovasi Pendidikan Kimia, 8(2), 1381.

Arikunto, S. (2014). Dasar-dasar Evaluasi Pendidikan. Jakarta: Bumi Aksara.

Azwar, S. (2012). Test Prestasi Fungsi dan Pengembangan Pengukuran Prestasi Belajar. Yogyakarta: Pustaka Pelajar.

Edlin, R. J. (2015). Hakikat Pendidikan Kristen. Jakarta: BPK Gunung Mulia.

Gery, G., Mering, A., \& Silaban, C. Y. (2018). EVALUASI PROGRAM PELATIHAN MUSIK DI PONTIANAK. Jurnal Pendidikan Dan Pembelajaran Khatulistiwa, 7(10), 1-10.

Handhika, J. (2012). Efektivitas media pembelajaran im3 ditinjau dari motivasi belajar. Jurnal Pendidikan IPA Indonesia, 1(2), 109-114. https://doi.org/10.15294/jpii.v1i2.2127

Indonesia, R. (2016). Peraturan Menteri Pendidikan dan Kebudayaan Republik Indonesia Nomor 23 Tahun 2016 tentang Standar Penilaian Pendidikan. Jakarta: Kementerian Pendidikan dan Kebudayaan.

Iswantiningtyas, V., \& Wulansari, W. (2018). Pentingnya Penilaian Pendidikan Karakter Anak Usia Dini. Proceedings of the kemampuan berpikir yang meningkat. Di samping perhatian terhadap aspek kompetensi dan jenis materi pembelajaran, penggunaan teknik penilaian berbasis test di Sekolah Minggu juga perlu memerhatikan aspek praktibilitas dan ekonomis, sesuai dengan kondisi pembelajaran di Sekolah Minggu yang padat aktivitas.

ICECRS $\quad 1(3), \quad$ 197-204. https://doi.org/10.21070/picecrs.v1i3.1396

L, R., \& Sitompul, H. (2016). Pengembangan Bahan Ajar Kegiatan Anak Sekolah Minggu Katolik di Gereja Katolik Tebing Tinggi. Jurnal Teknologi Informasi \& Komunikasi Dalam Pendidikan, 3(2), 142-143.

Lie, P. (2003). Mereformasi Sekolah Minggu. Yogyakarta: Andi.

Luhulima, D. A., Degeng, I. N. S., \& Ulfa, S. (2017). Pengembangan Video Pembelajaran Karakter Mengampuni Berbasis Animasi untuk Anak Sekolah Minggu. JINOTEP, 3(2), 111.

Mahirah. (2017). Evaluasi belajar peserta didik (siswa). Jurnal Idaarah, I(36), 257-267.

Mardapi, D. (2012). Pengukuran, Penilaian dan Evaluasi Pendidikan. Yogyakarta: Nuha Medika.

Matondang, Z., Djulia, E., Sriadhi, S., \& Simarmata, J. (2019). Evaluasi Hasil Belajar. Medan: Yayasan Kita Menulis.

Muchtar, H. (2010). Penerapan Penilaian Autentik dalam Upaya Peningkatan Mutu Pendidikan. Jurnal Pendidikan Penabur, 9(14), 71.

Prasetya, T. I. (2012). Meningkatkan Keterampilan Menyusun Instrumen Hasil Belajar Berbasis Modul Interaktif bagi Guru-Guru IPA SMPN Kota Magelang. Journal of Education Research and Evaluation, 1(2), 108.

Sanjaya, W. (2011). Kurikulum dan Pembelajaran 
Teori dan Praktik Pengembangan Kurikulum Tingkat Satuan Pendidikan. Jakarta: Kencana.

Sanjaya, W. (2015). Perencanaan dan Desain Sistem Pembelajaran. Jakarta: Kencana.

Setemen, K. (2010). Pengembangan evaluasi pembelajaran online. Jurnal Pendidikan Dan Pengajaran, 3(43), 207-214.

Subagia, I. W., \& Wiratma, I. G. L. (2016). Profil Penilaian Hasil Belajar Siswa Berdasarkan Kurikulum 2013. Jurnal Pendidikan Indonesia, 5(1), 39.
Widayati, W. (2013). Studi Deskriptif Tentang Bentuk-Bentuk Laporan Evaluasi Perkembangan Anak Di TK / RA / ABA Kecamatan Kertek Kabupaten WonosoboTahun 2013. Universitas Negeri Semarang.

Yusuf, A. M. (2015). Asesmen dan Evaluasi Pendidikan Pilar Penyedia Informasi dan Pengendali Mutu Pendidikan. Jakarta: Prenada Media.

Zahro, I. F. (2015). Penilaian dalam Pembelajaran Anak Usia Dini. Tunas Siliwangi, 1(1), 92. 